\title{
Penentuan Lokasi Sentra IKM Galendo untuk Meningkatkan Perekonomian Masyarakat Kabupaten Ciamis
}

\author{
Maria Nurhayaty ${ }^{1}$, Devy Dwi Orshella ${ }^{2 *}$ \\ ${ }^{1,2}$ Teknik Industri Universitas Galuh \\ Jln. R.E. Martadinata No. 150, Kab. Ciamis, Jawa Barat \\ ${ }^{2 *}$ devorshella@gmail.com
}

Dikirimkan: 11, 2019. Diterima: 11, 2019. Dipublikasikan: 03, 2020.

\begin{abstract}
Traditional food can provide a good image and economic improvement in an area. Ciamis Regency is known as a region producing traditional food, one of which is Galendo. The center of the sale and purchase of Galendo products in Ciamis Regency is still centered in a wholesale market that is less strategic. This research proposes the determination of the location of the Galendo IKM center and the development of various integrated facilities and infrastructure by the central government, which can be shared by other Galendo IKM. The determination of the location of the Galendo IKM center is analyzed by the center of gravity method. The distance of IKM location, production output, and transportation costs from 21 Galendo producers in the Cijeungjing, Cilame, Jendral Soedirman, Pawindan, Pamalayan, Sadananya, and Baregbeg areas are used to calculate the total transportation costs from each IKM location. The initial coordinate point is the location of the Ciamis Main Market which is compared with the 4 proposed coordinate points in order to produce the lowest total transportation costs. The total cost from the initial location of the Main Market is IDR 95,532,205. Whereas the total cost at proposed location 1 is only around $R p$ 80,015,976 which is lower than the initial location in the wholesale market.
\end{abstract}

Keywords-center of gravity; galendo; distance; IKM centers; total cost.

Abstrak- Keberadaan makanan tradisional suatu daerah dapat mengangkat citra positif daerah tersebut. Kabupaten Ciamis dikenal akan daerah penghasil berbagai jenis makanan tradisional, salah satu diantaranya adalah galendo. Kegiatan jual beli produk galendo di Kabupaten Ciamis masih berpusat di pasar induk yang lokasinya dinilai kurang strategis. Penentuan lokasi sentra IKM galendo diperlukan berikut dengan pengembangan berbagai sarana dan prasarana terpadu oleh pemerintah pusat, yang dapat digunakan bersama oleh para pelaku IKM. Penentuan lokasi sentra IKM galendo dilakukan menggunakan metode center of gravity. Jarak antar lokasi IKM, beban berupa output produksi, dan biaya transportasi dari 21 produsen Galendo yang tersebar di daerah Cijeungjing, Cilame, Jendral Soedirman, Pawindan, Pamalayan, Sadananya, dan Baregbeg digunakan untuk mengitung total biaya transportasi dari masing-masing titik lokasi IKM. Titik koordinat awal adalah lokasi Pasar Induk Ciamis yang dibandingkan dengan 4 titik koordinat usulan guna menghasilkan total biaya transportasi yang paling rendah. Total biaya jika sentra berada di lokasi awal yakni Pasar Induk, adalah mencapai Rp 95.532.205. Sedangkan total biaya di lokasi usulan 1 hanya berkisar Rp 80.015.976 yang lebih rendah dibandingkan dengan lokasi awal di pasar induk.

Kata kunci-center of gravity; galendo; jarak; sentra IKM; total biaya.

\section{PENDAhUluan}

Secara geografis, Kabupaten Ciamis terletak pada posisi strategis yang dilalui jalan nasional lintas provinsi Jawa Barat sampai Jawa Tengah [1]. Lebih dari $60 \%$ luas wilayah digunakan untuk kegiatan pertanian dan perkebunan. Sehingga potensi alam dari sektor tersebut menjadi kekuatan utama masyarakat Kabupaten Ciamis [2]. Disamping itu, kultur masyarakat pun dinilai masih menjunjung tinggi adat budaya dan kearifan lokal. Hal tersebut menjadikan Kabupaten Ciamis sebagai wilayah yang memiliki daya tarik wisata.

Potensi sumber daya alam di suatu daerah bisa dipilih menjadi produk unggulan terpilih di daerah tersebut, dengan menggunakan beberapa kriteria diantaranya sumber daya alam yang melimpah, kesiapan pemerintah, dan keunikan dari produk yang akan dihasilkan [3]. Menurut [4] konsep 
pengembangan inovasi di desa harus ada keterlibatan pihak perguruan tinggi dengan desa. Perguruan tinggi berperan sebagai pembina untuk kemajuan desa, dan sebagai fasilitator untuk pihak lain yang dibutuhkan. Beberapa kriteria dalam pengembangan potensi desa yaitu pemodalan, keterseiaan bahan baku, inovasi produk, kemasan yang menarik, promosi, sistem penjualan, dan manajemen usaha.

Keberadaan makanan tradisional suatu daerah dapat mengangkat citra positif daerah tersebut. Kabupaten Ciamis dikenal akan daerah penghasil berbagai jenis makanan tradisional. Salah satu diantaranya adalah galendo, yakni kudapan berbahan dasar kerak santan pada pembuatan minyak kelapa [5]. Peminat galendo umumnya akan meningkat pada masa balik lebaran, dimana rata-rata pedagang galendo mampu menjual hingga $100 \mathrm{~kg}$ [5]. Hal tersebut dikarenakan galendo hanya diproduksi oleh Industri Kecil dan Menengah di Kabupaten Ciamis. Hingga saat ini pun, galendo dikenal sebagai oleh-oleh khas daerah tersebut [6].

Sentra Industri Kecil dan Industri Menengah (Sentra IKM) adalah lokasi pemusatan kegiatan industri kecil dan industri menengah yang menghasilkan produk sejenis, menggunakan bahan baku sejenis dan atau mengerjakan proses produksi yang sama, dilengkapi sarana dan prasarana penunjang yang dirancang berbasis pada pengembangan potensi sumber daya daerah, serta dikelola oleh suatu pengurus profesional. Pengembangan Sentra Industri Kecil dan Industri Menengah merupakan amanah di dalam Undangundang No. 3 Tahun 2014 tentang Perindustrian. Pembangunan Sentra IKM umumnya diarahkan pada daerah-daerah yang belum memiliki Sentra IKM [7].

Berdasarkan data Dinas Koperasi UKM dan Perdagangan Kabupaten Ciamis (2017), industri kecil adalah jenis industri yang paling mendominasi hingga 86\% dari 10.127 unit industri di Kabupaten Ciamis. Adapun sentra IKM yang telah dibangun diantaranya industri kerupuk, makanan ringan, tahu, kue kering, sale pisang, dan gula merah. Namun di sisi lain, belum terdapat sentra IKM untuk produk galendo di Kabupaten Ciamis. Pada umumnya, peminat galendo membeli produk tersebut di pasar induk Kabupaten Ciamis. Jarak lokasi pasar dan sebaran IKM Galendo dapat dilihat pada gambar berikut:

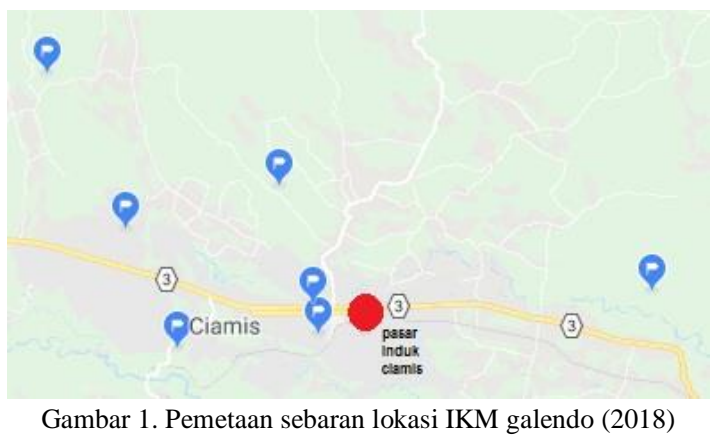

Pada gambar 1 terlihat lokasi pasar ada pada tanda merah, sedangkan tanda biru adalah lokasi IKM galendo yang tersebar di Kabupaten Ciamis. Berdasarkan pemetaan di atas dapat dilihat bahwa lokasi pasar belum tersentral dengan lokasi sebaran IKM galendo. Sehingga baik pemasok maupun pembeli produk galendo memerlukan satu titik lokasi strategis untuk menjadi sentra IKM galendo [11].

Pendekatan model gravitasi merupakan salah satu model empiris yang dinilai paling baik dalam mengatasi berbagai hambatan jarak perdagangan [10]. Dengan pendekatan ini, dapat ditentukan suatu titik koordinat dengan jarak terpendek dari total keseluruhan pusat pemasok yang menghasilkan biaya transportasi terendah [8][9].

Dalam penelitian ini, penentuan lokasi sentra IKM galendo akan dilakukan dengan menggunakan metode Center of gravity. Sehingga pusat kegiatan IKM galendo akan berlangsung di titik lokasi tersebut, berikut dengan pengembangan berbagai sarana dan prasarana terpadu oleh pemerintah pusat, yang dapat digunakan bersama oleh para pelaku IKM.

Penentuan lokasi menggunakan pendekatan center of gravity telah banyak dilakukan oleh penelitian sebelumnya. Diantaranya yakni pada penentuan lokasi fasilitas crossdock di kota metropolis Surabaya [13], lokasi gudang cabang di PT. ABC [14], lokasi pembangunan universitas baru di Campania Italy [12], lokasi gudang distribusi air mineral [16], hingga untuk menganalisis penyebaran kutu air di danau Ontario Amerika Utara [15]

\section{Metodologi PeNELITIAN}

Penentuan lokasi sentra IKM galendo akan dilakukan dengan menggunakan metode center of gravity. Penelitian diawali dengan survei ke lapangan mengenai permasalahan yang paling krusial untuk segera di tangani di IKM Kabupaten Ciamis. Berdasarkan survei tersebut, diketahui bahwa produk Galendo merupakan makanan khas 


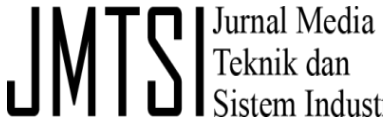

daerah yang banyak digemari oleh penduduk lokal, wisatawan domestik maupun luar daerah. Namun hingga saat ini, belum terdapat sentra IKM galendo sebagai pusat kegiatan IKM-IKM tersebut. Sehingga yang menjadi objek dalam penelitian ini adalah IKM galendo di Kabupaten Ciamis, dengan subyek dalam penelitian ini adalah para pemilik IKM galendo itu sendiri.

Dengan demikian, permasalahan dalam penelitian ini dirumuskan yakni bagaimana menentukan titik koordinat lokasi sentra IKM yang optimal guna meminimumkan total biaya transportasi. Penelitian akan dilanjutkan dengan mengumpulkan data berupa jarak antar lokasi IKM, beban berupa output produksi yang mereka angkut, dan biaya transportasinya. Nilai dari 3 variabel tersebut menjadi input untuk menentukan nilai koordinat X dan Y pada masing-masing lokasi IKM. Setelah mendapatkan nilai koordinat yang sesuai, kemudian dilanjutkan dengan menentukan beban maksimal produksi dan beban maksimal yang dapat diangkut oleh kendaraan angkut. Berdasarkan nilai tersebut, maka dapat dihitung jarak antara lokasi IKM, untuk kemudian ditentukan nilai koordinat X dan Y usulannya.

Nilai usulan tersebut dibandingkan terlebih dulu, jika tidak sesuai maka perlu dilakukan iterasi dengan menghitung kembali jarak antar lokasi IKM. Jika sudah diperoleh nilai yang sesuai, maka dapat dilanjutkan untuk mengitung total biaya transportasi dari masing-masiing titik lokasi IKM. Berdasarkan hasil keseluruhan penghitungan tersebut, maka diperoleh titik koordinat lokasi yang paling optimal untuk dijadikan lokasi sentra IKM galendo.

Namun untuk memastikan titik koordinat tersebut telah berada di lokasi yang paling strategis diantara sebaran IKM-IKM yang ada, maka perlu dilakukan perhitungan biaya transportasi pada titik koordinat awal dan titik koordinat usulan. Titik koordinat awal adalah lokasi Pasar Induk Ciamis, yang merupakan tempat para penjual dan pembeli galendo umumnya bertransaksi. Sedangkan titik koordinat usulan adalah lokasi hasil perhitungan menggunakan metode center of gravity. Dengan metode tersebut diharapkan biaya transportasi yang dihasilkan dapat lebih rendah dibanding titik koordinat awal yakni di Pasar Induk Ciamis.

Hasil dari seluruh pengolahan data tersebut kemudian disusun dalam laporan hasil penelitian untuk kemudian dipublikasikan. Adapun bagan rencana penelitian secara keseluruhan dapat dilihat pada Gambar 2 berikut:

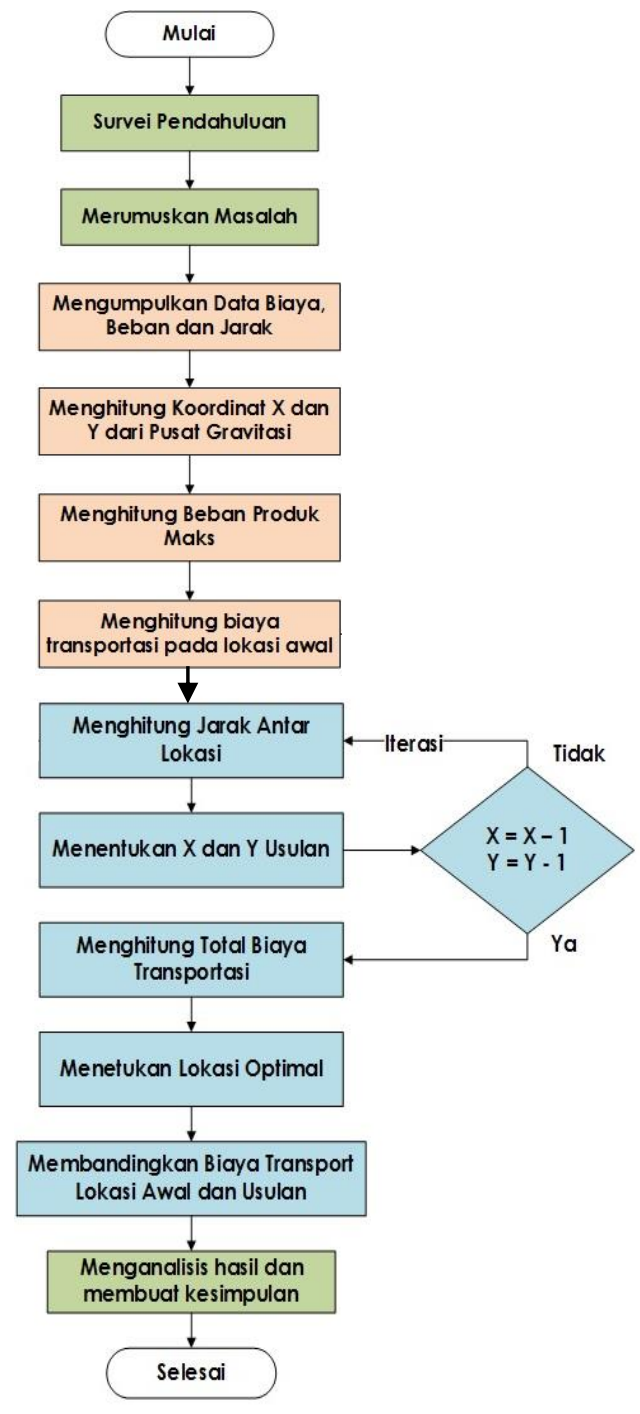

Gambar 2. Flowchart penelitian

\section{HASIL PENELITIAN}

Survei dilakukan untuk mendata IKM Galendo yang tersebar di Kabupate Ciamis. Data yang dikumpulkan adalah berupa data lokasi IKM Galendo ke pasar induk dan lokasi alternatif, lot produksi, dan biaya transportasi. Adapun data dan hasil pengolahan data dapat dilihat pada Tabel I dan II.

Berdasarkan hasil pendataan IKM Galendo di Kabupaten Ciamis, terdapat 21 produsen yang tersebar di daerah Cijeungjing, Cilame, Jendral Soedirman, Pawindan, Pamalayan, Sadananya, dan Baregbeg. Jarak, lot produksi, dan biaya transportasi ke lokasi sentra masing-masing IKM ke pasar induk diperoleh dari hasil survei. Adapun data jarak lokasi ditentukan menggunakan aplikasi Google Maps sesuai dengan titik koordinat saat 
berada di lokasi survei. Hasil pendataan IKM Galendo tersebut dapat dilihat pada Tabel I berikut:

TABEL I

DATA IKM GALENDO CIAMIS

\begin{tabular}{|c|c|c|c|}
\hline \multirow[t]{2}{*}{ IKM } & \multirow{2}{*}{$\begin{array}{c}\text { JARAK } \\
\text { PASAR } \\
\text { INDUK } \\
(\mathrm{KM})\end{array}$} & $\begin{array}{c}\text { LOT } \\
\text { PRODUKSI }\end{array}$ & $\begin{array}{c}\text { BIAYA } \\
\text { TRANSPORT } \\
\text { (Rupiah) }\end{array}$ \\
\hline & & $\mathbf{L i}$ & $\mathrm{Ci}$ \\
\hline P1 & 3,2 & 44 & 25.921 \\
\hline P2 & 4,5 & 48 & 29.355 \\
\hline P3 & 3,3 & 12 & 47.962 \\
\hline P4 & 3,6 & 41 & 32.585 \\
\hline P5 & 4,8 & 30 & 21.769 \\
\hline P6 & 4,1 & 17 & 35.774 \\
\hline P7 & 3,8 & 22 & 17.568 \\
\hline P8 & 3,6 & 39 & 21.909 \\
\hline P9 & 4,3 & 32 & 53.931 \\
\hline P10 & 4,7 & 45 & 41.357 \\
\hline P11 & 2,2 & 17 & 20.132 \\
\hline P12 & 3,3 & 16 & 46.423 \\
\hline P13 & 4,4 & 12 & 55.994 \\
\hline P14 & 4,1 & 41 & 39.301 \\
\hline P15 & 4 & 47 & 15.386 \\
\hline P16 & 3,8 & 23 & 47.828 \\
\hline P17 & 4,8 & 19 & 51.137 \\
\hline P18 & 2,9 & 45 & 56.113 \\
\hline P19 & 4,9 & 39 & 54.484 \\
\hline P20 & 3,3 & 37 & 59.411 \\
\hline P21 & 2,1 & 47 & 17.408 \\
\hline
\end{tabular}

Perhitungan total biaya menggunakan persamaan (1) berikut:

$$
\mathrm{TC}=\sum_{\mathrm{n}=1}^{\mathrm{i}} \mathrm{Fi} \times \mathrm{Li} \times \mathrm{Ci}
$$

Dimana:

$\mathrm{Fi}=$ Jarak antara lokasi IKM ke lokasi sentra

$\mathrm{Li}=$ Lot produksi

$\mathrm{Ci}=$ Total biaya transportasi

Berdasarkan persamaan (1) tersebut, kemudian dihitung total biaya keseluruhan pada tiap lokasi alternatif untuk kemudian dibandingkan dan ditentukan lokasi alternatif mana yang memberikan total biaya keseluruhan paling minimum.

Hasil perhitungan total biaya pada masingmasing lokasi IKM ke tiap alternatif lokasi dapat dilihat pada Tabel II berikut:
TABEL II

TOTAL BIAYA

\begin{tabular}{|c|c|}
\hline $\begin{array}{c}\text { LOKASI } \\
\text { SENTRA }\end{array}$ & $\begin{array}{c}\text { TC } \\
\text { (Rupiah) }\end{array}$ \\
\hline Awal & 92.532 .205 \\
\hline Usulan 1 & 80.015 .976 \\
\hline Usulan 2 & 92.218 .959 \\
\hline Usulan 3 & 85.235 .361 \\
\hline Usulan 4 & 81.643 .862 \\
\hline
\end{tabular}

\section{IV.PEMBAHASAN}

Pendekatan Model of Gravity didasarkan pada pemilihan koordinat titik suatu pusat distribusi yang memberikan jarak total terpendek terhadap keseluruhan pusat zona produksi yang harus dipasok. Data masing-masing jarak ke pasar induk, lot produksi, dan biaya transport masingmasing IKM galendo pada Tabel I kemudian digunakan untuk menentukan total biaya keseluruhan pada tiap alternatif lokasi.

Dengan demikian penentuan lokasi sentra diusulkan berdasarkan total biaya terkecil yang dihasilkan dari tiap alternatif lokasi, dimana total biaya terkecil tersebut berdasarkan jarak, lot produksi dan biaya transportasi.

Berdasarkan data pada Tabel II dapat dilihat bahwa total biaya jika sentra berada di lokasi awal yakni Pasar Induk, adalah mencapai $\mathrm{Rp}$ 95.532.205. Sedangkan total biaya di lokasi usulan 1 hanya berkisar Rp 80.015.976 yang lebih rendah dibandingkan dengan lokasi awal di pasar induk. Lokasi usulan sentra IKM galendo tersebut lebih menghemat biaya hingga 16,24\%.

Penurunan total biaya ini serupa dengan beberapa penelitian sebelumya yang menggunakan metode sejenis [17][18][19][20].

\section{KESIMPULAN}

Hal-hal yang dapat disimpulkan dari hasil penelitian ini diantaranya adalah alternatif lokasi sentra IKM galendo serta lokasi sentra terpilih yang ditentukan berdasarkan metode center of gravity.

Hasil pendataan IKM Galendo di Kabupaten Ciamis, terdapat 21 produsen yang tersebar di daerah Cijeungjing, Cilame, Jendral Soedirman, Pawindan, Pamalayan, Sadananya, dan Baregbeg dengan jarak, lot produksi, dan biaya transportasi ke lokasi sentra masing-masing IKM ke pasar induk. Total biaya jika sentra berada di lokasi awal yakni Pasar Induk, adalah mencapai $\mathrm{Rp}$ 
95.532.205. Sedangkan total biaya di lokasi usulan hanya berkisar $\mathrm{Rp} 80.015 .976$ yang lebih menghemat hingga 16,24\% dibandingkan dengan lokasi awal di pasar induk.

\section{UCAPAN TERIMA KASIH}

Penulis mengucapkan banyak terimakasih kepada pihak-pihak yang telah turut berpartisipasi, khususnya kepada:

1. DRPM kemenristekdikti

2. LLDIKTI 4 wilayah Jawa Barat \& Banten

3. LPPM Universitas Galuh

\section{REFERENSI}

[1] Pemerintah Provinsi Jawa Barat, "Geografi dan Iklim", Profil Daerah Kabupaten Ciamis, 2018, [online], tersedia: http://www.jabarprov.go.id [diakses: 24 Agustus 2018].

[2] BPS Kabupaten Ciamis, "Hasil Sensus Pertanian 2013", Katalog BPS, 2013, [online], tersedia: http://st2013.bps.go.id/st2013esya/booklet/st3207. pdf [diakses: 24 Agustus 2018].

[3] A. Sutoni, "Determination of regional main products with fuzzy logic approach in regional Sula Island of North Maluku Province," in 3rd International Conference on Digital Arts, Media and Technology, ICDAMT 2018, 2018, doi: 10.1109/ICDAMT.2018.8376488.

[4] A. Sutoni, "Determination of regional main products with fuzzy logic approach in regional Sula Island of North Maluku Province," in 3rd International Conference on Digital Arts, Media and Technology, ICDAMT 2018, 2018, doi: 10.1109/ICDAMT.2018.8376488.

[5] A. Sutoni and I. Masrofah, "Konsep Pengembangan Inovasi Keripik Gadung, Dalam Pemberdayaan Masyarakat di Desa Kutawaringin, Kecamatan Mande, Kabupaten Cianjur," IKRA-ITH Abdimas, vol. 1, no. 2, pp. 71-79, 2018.

[6] Nurhandoko, "Galendo Ciamis Mulai Naik Daun", Pikiran Rakyat, 2017, [online], tersedia: http://www.pikiran-

rakyat.com/kuliner/2015/08/02/336783/galendociamis mulai-naikdaun [diakses: 24 Agustus 2018]

[7] Pemerintah Provinsi Jawa Barat, "Makanan Galendo Khas Ciamis Jabar", Profil Daerah Kabupaten Ciamis, 2018, [online], tersedia: http://www.jabarprov.go.id [diakses: 24 Agustus 2018].

[8] Ditjen Pengembangan Perwilayahan Industri (PPI), "Informasi Umum Sentra IKM", Kementrian Perindustrian Republik Indonesia, 2017, [online], tersedia:

http://ppi.kemenperin.go.id/datainformasi/sentraik m_detail [diakses: 24 Agustus 2018].

[9] P. Parthiban dan G. Sundararaj, "Optimal Location of Base Station in a Wireless Sensor Network Using Gravity Location Model," International Journal of Engineering and Computer Science, vol. 2, no. 11, pp. 3147-3151, 2013.

[10] A. F. Elisa dan E. B. Santoso, "Penentuan FaktorFaktor yang Berpengaruh dalam Pengembangan Sentra Industri Alas Kaki di Kelurahan Kemasan Kecamatan Krian Kabupaten Sidoarjo Melalui Pendekatan Pengembangan Ekonomi Lokal", Jurnal Teknik ITS, vol. 6, no. 2, pp. 2337-3520, 2017.

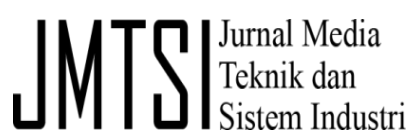

[11] Siswandi dan M. Krisnawati, "Pemilihan Lokasi Sentra Industri Batu Klawing Purbalingga dengan Metode AHP”, Jurnal Dinamika Rekayasa, vol. 12, no. 1, pp. 39-44, 2016

[12] F. P. Rini dan A. Y. Koswara, "Faktor Penentu Lokasi Sentra Industri Kecil Pengolahan

[13] Hasil Perikanan Tangkap di Kawasan Pesisir Kota Pasuruan", Jurnal Teknik ITS, vol. 6, no. 2, pp. 2337-3520, 2017.

[14] I. Hakim, "Kajian Pemilihan Lokasi Industri Pengolahan Batu Alam: Studi kasus Sentra Industri Batu Alam di Kabupaten Magelang", Electronic Theses \& Dissertations, Universitas Gadjah Mada, 2009.

[15] M. T. Dasfordate, "Penentuan Alternatif Lokasi Gudang Akhir Rumput Laut Dengan Metode Center of gravity Dan Point Rating" ARIKA: Media Ilmuan dan Praktisi Teknik Industri, vol. 06, no. 2, pp. 115124, 2012.

[16] G. Bruno dan G. Improta, "Using gravity models for the evaluation of new university site locations: A case study," ELSEVIER, vol. 35, no. 2, pp. 436444, 2008.

[17] M. Anshori, A. F. Fudhla, dan A. Hidayat, "Penentuan Lokasi Fasilitas Crossdock pada Kota Metropolis dengan Pendekatan Center of gravity", Teknika: Engineering and Sains Journal, vol. 1, no. 2, pp. 83-88, 2017

[18] E. W. Yunitasari, "Metode Gravity Location Models Dalam Penentuan Lokasi Cabang Yang Optimal," Jurnal Ilmiah Teknik Industri dan Informasi, vol. 3, no. 2, pp. 75-82, 2015.

[19] Potapov, et al, "Stochastic gravity models for modeling lake invasions," ELSEVIER, vol. 222, no. 4, pp. 964-972, 2011.

[20] E. Adriantantri, Y. A. Pranoto, dan T. Priyasmanu, "Aplikasi Penentuan Lokasi Gudang Distribusi Air Mineral Menggunakan Gravity Location Model", Jurnal Teknologi Informasi, vol. 6, no. 2, pp. 83-92, 2015 . 